\title{
Task-based Language Teaching to Develop Malay Language Speaking Skills among Primary 5 Singaporean Students
}

\author{
Zainaba Omar, Norliza Jamaludin, Mahzan Arshad \\ Education University of Sultan Idris, Malaysia
}

ozasrid05@gmail.com

First draft received: 10 Aug 2020 Date Accepted: 21 Jan 2021 Final proof received: 21 Apr 2021

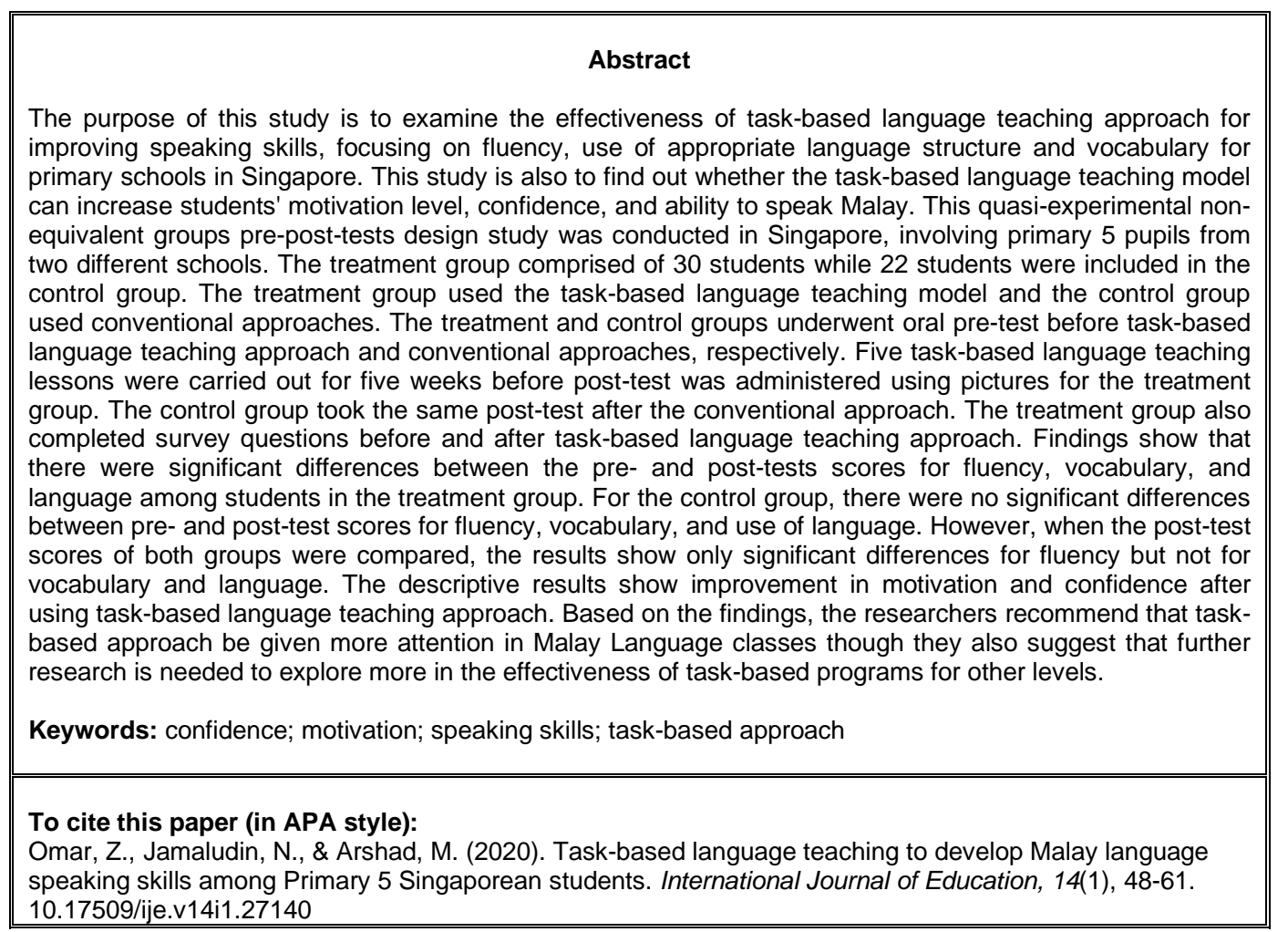

\section{INTRODUCTION}

Singapore, a small multi-racial, multi-religious, and multi-cultural country that relies heavily on an economy with no natural resources, faces the challenge of developing its people to their optimum to survive. It needs a good education system to benefit from globalisation while maintaining its values and culture. Thus, to survive in a globalised world, Singapore has positioned the English language as an important subject in its educational system, promoting the teaching of 'standard English' as an important educational initiative to make the country globally competitive. To counterbalance the effect of the
Westernisation of Singaporeans through the globalisation of undesirable values and practices, teaching and learning the mother tongues (Chinese, Malay, and Tamil) as second languages has also been made compulsory. This was done to ensure that Singaporeans remained rooted in their local cultures and histories and did not waver in their respect for Asian traditions and values (Gopinathan, 2010) Thus, bilingualism has become the cornerstone of the education system in Singapore. Among the objectives of learning a second language or a mother-tongue language is to enable students to understand and build their own unique identity through a deep 
appreciation of their culture, tradition, literature and ethnic history (Lee, 2012) In addition, the Singaporean government wants to ensure that its mother-tongue languages remain living languages and are not used just for examination purposes (Lee, 1999).

However, the profound emphasis on English as a working language and its role as a language of globalisation have indeed made it a crucial subject in schools. Consequently, an increasing number of primary school students are speaking English more than their own mother tongue. Statistical data from the Ministry of Education show that more and more Primary 1 students are speaking only English at home. Figure 1 illustrates that in all three ethnic groups in Singapore (Zhou, 2019), the percentage of Primary 1 students speaking English at home has increased since 1999.

Figure 1

Percentage of Primary 1 students speaking mother tongue language at home

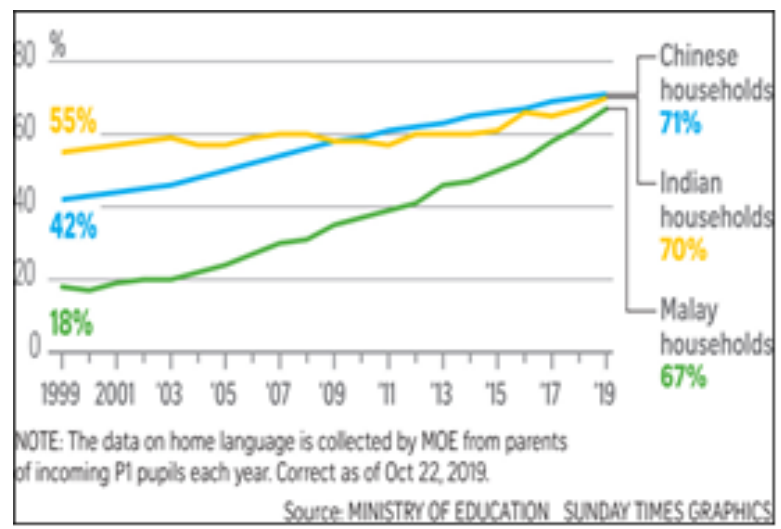

Meanwhile, a 2010 survey conducted by the Ministry of Education's Mother Tongue Language Curriculum Review Committee also found that this bilingual policy has caused more Malay families to use English at home, but some of them are not able to converse in their own language. As a result, many students have problems speaking, reading, and writing in Malay. They possess a limited vocabulary, which makes it hard for them to conduct fluent conversations in Malay. They find it more comfortable to converse in English even though they are part of the Malay language class. Also, this report highlighted that teachers had to use translation methods when teaching Malay to help the students understand what was being taught. The plight of teachers has worsened because of the shorter time allocated to teach the second language compared to English. This has resulted in students' reduced exposure to the Malay language and limited vocabulary. The students always code-switch to English while speaking, which has become a habit in the classroom. In addition, the emphasis on the use of English has also caused teachers to interact in English with students who cannot speak or are not interested in the Malay language (MOE, 2010). The situation has worsened because of the lack of parental encouragement regarding the Malay language learning process at schools. In reality, most students enter school with limited Malay language skills or with no basic knowledge at all. This has prompted parents and students to question the value and effectiveness of teaching Malay (MOE, 2005, 2010). Therefore, this language is no longer used to interact with friends, teachers, or society, but English is a must for communication (MOE, 2011). Moreover, classroom observations carried out by the Ministry of Education found less participation from students in teaching and learning activities. Many Malay language teachers still practise the lecture or explanation method, and while it does not conflict with teaching and learning principles, it is no longer suitable for use, as it does not help in developing students' minds (Baki, 2003; Brown, 2000), especially for those who do not use the language that much outside the classroom (MOE, 2005, 2010).

If this scenario continues, students' Malay language mastery will continue to decline, eventually leading to inter-language fossilisation. Therefore, a policy goal emphasising mastery of and fluency in two languages will only be an obstacle and will not be achievable if this issue is not addressed in the long run. Since today's students have problems learning and speaking the Malay language, it is worthwhile to build a model that can help teachers instruct on speaking skills by highlighting students' active participation. To ensure that the Malay language is kept alive and used by students, an approach is needed to expose the Malay language in class, so they have a chance to use it correctly and efficiently. The task-based language teaching approach was introduced in 1987 by N.S. Prabhu in his Bangalore project, which attracted much interest. According to Van den Branden (2006), functional tasks given in task-based language teaching approach provide students with the opportunity to use the target language more meaningfully. Task-based language teaching approach does not highly emphasise grammar teaching before students can speak the language; rather, they will be able to learn grammar through observing and performing the tasks. This will help them master the language and skills (Bygate et al., 2021; Van den Branden, 2016). Willis and Willis (2007), Van den Branden (2006), Ellis (2003), Skehan (1998), and Long and Crookes (1992) stated that students learn a language efficiently through tasks because by performing them, they will be able to communicate and interact with one another. Through such interaction, students will be able to understand and also be understood. Mao (2012) reiterated that task-based language teaching approach also provides an opportunity for language learning to take place through interaction, and Task-based language teaching approach is in line with the needs of today's extremely student-centred classroom. A study conducted by Rohani (2011) on tertiary students in Indonesia showed that tasks help students focus on 
meaning, which will stimulate their learning and encourage them to use the language more. A similar study carried out in Pakistan by Buriro and Hayat (2010) claimed that task-based language teaching approach can promote student-teacher negotiations within a collaborative environment. The findings showed that students' proficiency level increased after they performed and reflected on the tasks.

Studies have also shown that task-based language teaching approach could provide intrinsic motivation, encourage active participation in class, and increase communication and collaboration (Barnard \& Viet, 2010; Jong, 2006; Plews \& Zhao, 2010; Xiong \& Moses, 2011). Another study conducted by Thanh and Huan (2012) found that task-based language teaching approach highly motivated students to complete meaningful and challenging tasks. In addition, their vocabulary acquisition also increased.

Various task-based language teaching designs have been proposed and used (Ellis, 2003; Gatbanton \& Gu, 1994; Willis, 1996), all of which have three principal phases in common, that is, pre-task, during task, and post-task. This research modified the models presented by Willis and Ellis, which was deemed necessary based on the profile of students in Singapore who are learning their mother tongue as a second language. Figure 2 shows the task-based language teaching model, modified from Willis's and Ellis's models, which was used in this research.

\section{Figure 2}

Modified task-based language teaching model

\begin{tabular}{|c|c|c|c|}
\hline Models & Pre-task & During Task & Post Task \\
\hline Ellis & $\begin{array}{l}\text { Introduction } \\
\& \text { Task } \\
\text { modelling }\end{array}$ & $\begin{array}{l}\text { Task } \\
\text { presentation }\end{array}$ & $\begin{array}{l}\text { Introduction } \\
\text { and task } \\
\text { modelling }\end{array}$ \\
\hline Willis & $\begin{array}{l}\text { Introduction } \\
\& \text { Task } \\
\text { modelling }\end{array}$ & $\begin{array}{l}\text { Task } \\
\text { presentation } \\
\text { Planning and } \\
\text { presenting } \\
\text { reports }\end{array}$ & $\begin{array}{l}\text { Language } \\
\text { analysis in } \\
\text { reports and } \\
\text { language } \\
\text { practice }\end{array}$ \\
\hline Modified & $\begin{array}{l}\text { Introduction } \\
\text { \& task } \\
\text { modelling }\end{array}$ & $\begin{array}{l}\text { Planning \& } \\
\text { Practicing of } \\
\text { task }\end{array}$ & $\begin{array}{l}\text { Presentation } \\
\text { of task } \\
\text { Assessment } \\
\text { Explicit } \\
\text { language } \\
\text { component } \\
\text { teaching }\end{array}$ \\
\hline
\end{tabular}

In the modified model, the task is introduced and modelled for the students. Afterward, the students plan and practise how they are going to perform the task. Finally, students will do the task. During the presentation, the teacher guides students to conduct peer assessment. Teacher will assess at the same time. The teacher highlights the correct words or phrases used during the presentation and at the same time checks for mistakes in the language. The teacher then teaches the language component explicitly and concludes the lesson language practice.
Therefore, this study examines whether there is a significant difference in speaking skill achievement in students who undergo the conventional task-based language teaching approach in learning Malay. The findings will clearly determine the viability of the taskbased language teaching model as vital tool in teaching and learning speaking skills among P5 Malay language learners.

\section{METHOD}

This study used a quasi-experimental design of preand post-tests for unbalanced groups.

\section{Participants}

To accomplish the current research, sampling was conducted at two schools with similar socio-economic backgrounds. The schools were neighbourhood schools in two different zones, using similar instructional materials and syllabus provided by the Ministry of Education. The students were native Malay who either unable or refuse to speak the language. A total of 30 students from the first school were the treatment group, while another 22 from the second school were selected to be the control group.

\section{Instruments}

The researcher used pictures and stimulus questions for pre-test and post-test. In addition, treatment group also completed a questionnaire for motivation and confidence after TBTL. 5 TBTL lesson plans were developed based on the themes used in the instructional materials used in the school.

\section{Procedures}

The researcher trained the teacher and TBTL lessons commenced only started after the teacher was confident of carrying out the lessons. Both groups underwent a pre-test before the task-based language teaching approach was implemented (Appendix 1). After the pre-test, students in the treatment group were taught by the teacher using task-based language teaching for 5 weeks (Appendix 2), while the control group was taught using the conventional approach through self-directed activity as in the instructional material package (designed by Singapore Ministry of Education) for the same duration.

Lesson started with the teacher explaining the objectives and showing the model of the task the students have to complete. Teacher brainstormed the vocabulary needed to complete the task. At the preparation level, students discussed and rehearsed how to present the task. Students were required to present their task either by presenting their poster or role-play. During the presentation, teacher evaluation and peer evaluation were conducted. And finally, teacher distinguished the language aspect that required teaching. Teacher then taught the language component explicitly. After the completion of the 5 lessons, both groups underwent a post-test (Appendix 3). Both pre-test and post-test were evaluated using a rubric (Appendix 4). 


\section{RESULTS}

The Kolmogorov-Smirnov test showed an abnormal data distribution $(p<.05)$. Therefore, a non-parametric test was performed to determine the difference between pre-measurement and post-measurement for the three test elements. In addition, the Wilcoxon signed-rank and Mann-Whitney $U$ tests were also used for inference statistics analysis.

\section{Treatment Groups}

Pre- and post-test fluency score analysis

Table 1.1

Descriptive statistics

\begin{tabular}{|c|c|c|c|c|c|c|c|c|}
\hline & \multirow[b]{2}{*}{$\mathrm{N}$} & \multirow[b]{2}{*}{ Min } & \multirow[b]{2}{*}{$\begin{array}{l}\text { Standard } \\
\text { Deviation }\end{array}$} & \multirow[b]{2}{*}{ Minimum } & \multirow[b]{2}{*}{$\begin{array}{l}\text { Maximu } \\
\mathrm{m}\end{array}$} & \multicolumn{3}{|c|}{ Percentile } \\
\hline & & & & & & 25th & $\begin{array}{l}\text { 50th } \\
\text { (Median) }\end{array}$ & 75th \\
\hline $\begin{array}{l}\text { Fluency } \\
\text { (pre) - }\end{array}$ & 30 & 4.93 & 1.33 & 2.00 & 7.00 & 4.00 & 5.00 & 6.00 \\
\hline $\begin{array}{l}\text { Fluency } \\
\text { (post) }\end{array}$ & 30 & 6.20 & 1.51 & 3.00 & 9.00 & 5.00 & 7.00 & 7.00 \\
\hline
\end{tabular}

Table 1.2

Ranks

\begin{tabular}{lllll}
\hline & & $\mathrm{N}$ & Min Ranks & Total Ranks \\
\hline Fluency (pre) & - Negative Ranks & 0 & .00 & .00 \\
Fluency (post) & Positive Ranks & 21 & 11.00 & 231.00 \\
& Equal & 9 & & \\
& Total & 30 & & \\
\hline
\end{tabular}

Table 1.3

Test statistics

\begin{tabular}{ll}
\hline & Fluency (pre) - Fluency (post) \\
\hline$Z$ & -4.075 \\
Asymp. & Sig. .000 \\
(2-tailed) & \\
\hline
\end{tabular}

The results of the Wilcoxon signed-rank test in Table 1.2 show a significant difference in the fluency aspect for the treatment group, $Z=-4.075, p<.001$. The study result shows that after treatment, the resulting score (median $=7.00$ ) was higher than the before-treatment score (median $=5.00$ ), as shown in Table 1.1. This indicates that task-based language teaching significantly improves students' speaking skills.

\section{Pre- and post-test vocabulary score analysis}

Table 2.1

Descriptive statistics

\begin{tabular}{lllllllll}
\hline & N & Min & $\begin{array}{c}\text { Standard } \\
\text { Deviation }\end{array}$ & Minimum & Maximum & \multicolumn{2}{l}{ Percentile } & \\
\hline Vocabulary (pre) 30 & 4.56 & 1.30 & 2.00 & 8.00 & 3.75 & 5.00 & 5.00 \\
- & & & & & & & & \\
Vocabulary (post) 30 & 5.66 & 1.39 & 3.00 & 8.00 & 4.75 & 6.00 & 7.00 \\
\hline
\end{tabular}

Table 2.2

Ranks

\begin{tabular}{lllll}
\hline & & $\mathrm{N}$ & Min Ranks & Total Ranks \\
\hline Vocabulary (pre) & Negative Ranks & 1 & 6.50 & 6.50 \\
-Vocabulary & Positive Ranks & 22 & 12.25 & 269.50 \\
(post) & Equal & 7 & & \\
& Total & 30 & & \\
\hline
\end{tabular}

Table 2.3

Test statistics

\begin{tabular}{ll}
\hline & Vocabulary (post) - Vocabulary (pre) \\
\hline$Z$ & -4.108 \\
Asymp. Sig. & .000 \\
(2-tailed) & \\
\hline
\end{tabular}

The result of the Wilcoxon signed-rank test in Table 2.2 also shows a significant difference in the vocabulary aspect for the treatment group, $Z=-4.108$, $p<.001$. The study result shows that the vocabulary score after treatment (median $=6.00$ ) was higher than the one before treatment (median $=5.00$ ) as shown in Table 2. This also indicates that the students' speaking skills in Malay improved significantly through task-based language teaching approach.

\section{Pre- and post-test language score analysis}

Table 3.1

Descriptive statistics

\begin{tabular}{|c|c|c|c|c|c|c|c|c|}
\hline & \multirow[b]{2}{*}{$\mathrm{N}$} & \multirow[b]{2}{*}{ Min } & \multirow[b]{2}{*}{$\begin{array}{l}\text { Standard } \\
\text { Deviation }\end{array}$} & \multirow[b]{2}{*}{ Minimum } & \multirow[b]{2}{*}{ Maximum } & \multicolumn{3}{|c|}{ Percentile } \\
\hline & & & & & & & $\begin{array}{l}\text { 50th } \\
\text { (Median) }\end{array}$ & 75th \\
\hline $\begin{array}{l}\text { Bahasa } \\
\text { (pre) }\end{array}$ & 30 & 4.60 & 1.35 & 2.00 & 7.00 & 4.00 & 4.50 & 5.00 \\
\hline $\begin{array}{l}\text { Bahasa } \\
\text { (post) }\end{array}$ & 30 & 5.70 & 1.60 & 2.00 & 9.00 & 5.00 & 6.00 & 7.00 \\
\hline
\end{tabular}

Table 3.2

Ranks

\begin{tabular}{|c|c|c|c|c|}
\hline & & $\mathrm{N}$ & Min Ranks & Total Ranks \\
\hline Language (post) & Negative Ranks & 3 & 8.50 & 25.50 \\
\hline \multirow[t]{3}{*}{ Language (pre) } & Positive Ranks & 22 & 13.61 & 299.50 \\
\hline & Equal & 5 & & \\
\hline & Total & 30 & & \\
\hline
\end{tabular}

Table 3.3

Test statistics

\begin{tabular}{ll}
\hline & Language (post) - Language (pre) \\
\hline$Z$ & -3.811 \\
Asymp. Sig. & .000 \\
(2-tailed) & \\
\hline
\end{tabular}

Other than that, the Wilcoxon signed-rank test results in Table 3.2 show a significant difference in the language aspect for the treatment group, $Z=-3.811, p$ $<.001$. This shows that the language score after treatment (median $=6.00$ ) is higher than the one before treatment (median $=4.50$ ), as shown in Table 3. Again, this indicates an improvement in speaking skills among students after task-based language teaching.

CONTROL GROUP

Pre- and post-test fluency score analysis

Table 4 


\begin{tabular}{|c|c|c|c|c|c|c|c|c|}
\hline & \multirow{2}{*}{$\mathrm{N}$} & \multirow{2}{*}{ Min } & \multirow{2}{*}{$\begin{array}{l}\text { Standard } \\
\text { Deviation }\end{array}$} & \multirow{2}{*}{ Minimum } & \multirow{2}{*}{ Maximum } & \multicolumn{3}{|c|}{ Percentile } \\
\hline & & & & & & 25 th & 50th (Median) & 75th \\
\hline $\begin{array}{l}\text { Fluency (pre) } \\
\text { - }\end{array}$ & 22 & 4.90 & 1.230 & 1.00 & 7.00 & 4.00 & 5.00 & 6.00 \\
\hline Fluency (post) & 22 & 5.22 & .921 & 3.00 & 7.00 & 5.00 & 5.00 & 6.00 \\
\hline
\end{tabular}

Table 4.2

Ranks

\begin{tabular}{|c|c|c|c|c|}
\hline & & $\mathrm{N}$ & Min Ranks & Total Ranks \\
\hline Fluency (post) & - Negative Ranks & 5 & 7.60 & 38.00 \\
\hline \multirow[t]{3}{*}{ Fluency (pre) } & Positive Ranks & 9 & 7.44 & 67.00 \\
\hline & Equal & 8 & & \\
\hline & Total & 22 & & \\
\hline
\end{tabular}

Table 4.3

Test statistics

\begin{tabular}{ll}
\hline & Fluency (post) - Fluency (pre) \\
\hline$Z$ & -.941 \\
Asymp. Sig. & .347 \\
(2-tailed) & \\
\hline
\end{tabular}

For the control group, the Wilcoxon signed-rank test results in Table 4.2 show no significant difference in this aspect before treatment (median $=5.00$ ) and after treatment $($ median $=5.00), Z=-.941, p>.05$. This indicates no improvement in speaking skills after using the conventional method.

\section{Pre- and post-test vocabulary score analysis}

Table 5

Descriptive statistics

\begin{tabular}{lllllllll}
\hline & $N$ & Min & $\begin{array}{l}\text { Standard } \\
\text { Deviation }\end{array}$ & Minimum & Maximum & \multicolumn{2}{l}{ Percentile } \\
\cline { 7 - 8 } & & & 25 th & 50 th (Median) & 75 th \\
\hline $\begin{array}{l}\text { Vocabulary } \\
\text { (pre) }-\end{array}$ & 22 & 5.09 & 1.50 & 1.00 & 8.00 & 4.00 & 5.00 & 6.00 \\
$\begin{array}{l}\text { Vocabulary } \\
\text { (post) }\end{array}$ & 22 & 5.36 & 1.00 & 3.00 & 7.00 & 5.00 & 5.50 & 6.00 \\
\hline
\end{tabular}

Table 5.1

Ranks

\begin{tabular}{lllll}
\hline & & $\mathrm{N}$ & Min Ranks & Total Ranks \\
\hline Vocabulary (pre) & Negative Rank & 5 & 9.20 & 46.00 \\
- Vocabulary & Positive Rank & 10 & 7.40 & 74.00 \\
(post) & Equal & 7 & & \\
& Total & 22 & & \\
\hline
\end{tabular}

Table 5.2

Test statistics

\begin{tabular}{ll}
\hline & Vocabulary (post) - Vocabulary (pre) \\
\hline$Z$ & -.810 \\
Asymp. Sig. & .418 \\
(2-tailed) & \\
\hline
\end{tabular}

The results of the Wilcoxon signed-ranks test in Table 5 also show no significant difference in the vocabulary aspect before treatment (median $=5.00$ ) and after treatment (median $=5.00), Z=-.810, p>$ .05 , indicating no significant improvement in speaking skills after undergoing the conventional method.

\section{Pre- and post-test language score analysis}

Table 6.1

\begin{tabular}{|c|c|c|c|c|c|c|c|c|}
\hline & \multirow{2}{*}{$\mathrm{N}$} & \multirow[b]{2}{*}{ Min } & \multirow{2}{*}{$\begin{array}{l}\text { Standard } \\
\text { Deviation } \\
\end{array}$} & \multirow[b]{2}{*}{ Minimum } & \multirow[b]{2}{*}{ Maximum } & \multicolumn{3}{|c|}{ Percentile } \\
\hline & & & & & & 25 th & 50th (Median) & 75 th \\
\hline Language (pre) & 22 & 5.09 & 1.50 & 1.00 & 8.00 & 4.00 & 5.00 & 6.00 \\
\hline $\begin{array}{l}\text { Language } \\
\text { (post) }\end{array}$ & 22 & 5.72 & .93 & 4.00 & 7.00 & 5.00 & 6.00 & 6.00 \\
\hline
\end{tabular}

Table 6.1

Ranks

\begin{tabular}{|c|c|c|c|c|}
\hline & & $\mathrm{N}$ & Min Ranks & Total Ranks \\
\hline Language (post) - & Negative Ranks & 4 & 10.13 & 40.50 \\
\hline \multirow[t]{3}{*}{ Language (pre) } & Positive Ranks & 13 & 8.65 & 112.50 \\
\hline & Equal & 5 & & \\
\hline & Total & 22 & & \\
\hline
\end{tabular}

Table 6.2

Test statistics

\begin{tabular}{ll}
\hline & Language (post) - Language (pre) \\
\hline$Z$ & -1.761 \\
Asymp. Sig. & .078 \\
(2-tailed) & \\
\hline
\end{tabular}

Furthermore, the Wilcoxon signed-rank test results in Table 6 also show that there was no significant difference in the language aspect after treatment (median $=6.00$ ) and before treatment (median $=5.00), Z=-1.761, p>.05$. Again, this shows little improvement in speaking skills after going through the conventional method of learning the Malay language.

\section{Control and treatment groups' post-test score differences}

Table 7.1

Descriptive statistics

\begin{tabular}{|c|c|c|c|c|c|c|c|c|}
\hline \multicolumn{9}{|l|}{ Fluency } \\
\hline & \multirow[t]{2}{*}{$\mathrm{N}$} & \multirow[t]{2}{*}{ Min } & \multirow{2}{*}{$\begin{array}{l}\text { Standard } \\
\text { Deviation }\end{array}$} & \multirow[t]{2}{*}{ Minimum } & \multirow[t]{2}{*}{ Maximum } & \multicolumn{3}{|c|}{ Percentile } \\
\hline & & & & & & 25th & 50th (Median) & 75th \\
\hline \multicolumn{9}{|l|}{ Group } \\
\hline Treatment & 30 & 6.20 & 1.51 & 3.00 & 9.00 & 5.00 & 7.00 & 7.00 \\
\hline Control & 22 & 5.22 & .921 & 3.00 & 7.00 & 5.00 & 5.00 & 6.00 \\
\hline \multicolumn{9}{|c|}{ Vocabulary } \\
\hline & $\mathrm{N}$ & Min & Standard & Minimum & Maximum & \multicolumn{3}{|c|}{ Percentile } \\
\hline \multirow{2}{*}{\multicolumn{9}{|c|}{ 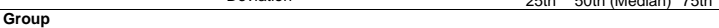 }} \\
\hline & & & & & & & & \\
\hline Treatment & 30 & 5.66 & 1.39 & 3.00 & 8.00 & 4.75 & 6.00 & 7.00 \\
\hline Control & 22 & 5.36 & 1.00 & 3.00 & 7.00 & 5.00 & 5.50 & 6.00 \\
\hline \multicolumn{9}{|l|}{ Language } \\
\hline & \multirow[t]{2}{*}{$\mathrm{N}$} & \multirow[t]{2}{*}{ Min } & \multirow{2}{*}{$\begin{array}{l}\text { Standard } \\
\text { Deviation }\end{array}$} & \multirow[t]{2}{*}{ Minimum } & \multirow[t]{2}{*}{ Maximum } & \multicolumn{3}{|c|}{$\begin{array}{l}\text { Percentile } \\
\end{array}$} \\
\hline & & & & & & 25th & 50th (Median) & 75th \\
\hline \multicolumn{9}{|l|}{ Group } \\
\hline Treatment & 30 & 5.70 & 1.60 & 2.00 & 9.00 & 5.00 & 6.00 & 7.00 \\
\hline Control & 22 & 5.72 & .93 & 4.00 & 7.00 & 5.00 & 6.00 & 6.00 \\
\hline
\end{tabular}

Table 7.2

Test statistics

\begin{tabular}{llll}
\hline & Fluency (post) & Vocabulary (post) & $\begin{array}{l}\text { Language } \\
\text { (post) }\end{array}$ \\
\hline & & & \\
\hline Mann-Whittney U & 190.000 & 279.000 & 325.500 \\
Wilcoxon W & 443.000 & 532.000 & 578.500 \\
Z & -2.679 & -.971 & -.087 \\
Asymp. Sig. & .007 & .331 & .931 \\
(2-tailed) & & & \\
\hline
\end{tabular}

The Mann-Whitney $U$ test scores in Table 7 shows higher achievement in the fluency aspect for the treatment group after using task-based language teaching (median $=7.00)$ compared with the control group (median $=5.00), U=190.00, p<.05$. However, the same test also showed no significant difference 
between both groups in the vocabulary aspect, $U=$ $279.00, p>.05$, or the language aspect, $U=325.50, p$ $>.05$, after using task-based language teaching approach.

\section{DISCUSSION \\ Fluency Aspect}

The research findings in Table 1 show a significant difference between pre-test and post-test scores for the treatment group. Fluency can be defined as the ability to speak without stumbling by using suitable intonation and to relate spoken ideas cohesively and coherently. The results of the Wilcoxon signed-rank test show a significant difference in the fluency aspect, $\mathrm{Z}=-4.075, \mathrm{p}<.001$. The fluency score (median $=$ 7.00) was higher after treatment than before treatment (median $=5.00$ ). This significant difference shows that the tasks used in task-based language teaching approach help students speak fluently. These findings are parallel with those of Nunan (2004), Ellis (2003), and Willis (1996), that task-based language teaching could help students learn a language efficiently. In addition, these findings support Mao's (2012) conclusion that an approach such as task-based language teaching approach can give students the chance to interact using the target language and that such an approach is necessary to achieve language skill objectives. Moreover, these findings are in line with the research by Torky (2006) in Egypt, which found that task-based language teaching can help students accept the challenge of performing the given tasks and speak fluently. Aliakbari and Jamalvandi (2010) strengthened these findings by stating that task-based language teaching helped students in Iran to speak the English language fluently. These findings are also in accordance with those of Buriro and Hayat (2010), who found that task-based language teaching succeeded in helping the students use the target language fluently in Pakistan. This established that this group of students improved their speaking skills after conducting activities and reflecting on their learning.

For the control group, the study findings in Table 4 show no significant difference in fluency before treatment (median $=5.00$ ) and after treatment (median $=5.00), Z=-.941, p>.05$. This proves that the conventional approach does not affect how the students speak. These findings are in parallel with the opinion of Skehan $(1998,2001)$ that the effectiveness of a conventional approach such as presentation, practice, and production (PPP) is questionable in helping teach speaking skills because these skills require not only grammar exercises but also exposure to meaningful tasks. The findings from this study also strengthen the research by DeKeyser (2007), who stated that the conventional approach uses fewer tasks in teaching and may result in students' inability to communicate well in the target language even if they have been learning it for years. Meanwhile, the study findings are also consistent with those of the study summary done by Frost (2014), who concluded that while conventional methods such as PPP can make students speak confidently in the classroom, they won't be able to use the learned language or will find it difficult to do so while speaking after the learning session.

In conclusion, the study findings prove that taskbased language teaching tasks can expose students to an environment where they can use the language fluently. The tasks can motivate students to make mistakes and learn from them by noticing them while interacting. Without exposure to such an environment, students will find it difficult to use the target language. This will prevent them from applying their mastery by speaking fluently.

\section{Language and Vocabulary Aspects}

From a Malay vocabulary usage standpoint, the findings from the study, as shown in Table 2, reveal a significant difference for the treatment group, $Z=$ $4.108, p<.00$. The vocabulary score after treatment (median $=6.00$ ) was higher than that before treatment (median $=5.00)$. Besides, the study findings in the language aspect in Table 3 also show a significant difference in the treatment group, $Z=-3.811, p<.001$. The language score after treatment (median $=6.00$ ) was higher than that before treatment (median $=4.50$ ).

These study findings are supported by Krashen (2003), who highlighted that exposure to a meaningful environment can help students understand challenging language inputs to master language knowledge. Also, significant differences may have been observed because the students had a chance to receive feedback when their mistakes were corrected by paraphrasing them to ensure the interlocutor understood the speech, or to ask for clarification when completing the tasks. This view is supported by Swain (1985), who argued that a positive environment for language learning will positively pressure the student to utter understandable inputs and directly expand their language mastery.

In addition, the study findings also agree with the views of Howatt (1984), Bygate and Norris (2009), and Van and Branden (2012), who stated that task-based language teaching emphasises fluency and precision of meaning to help students master vocabulary and language knowledge. Therefore, activities done in a given task will motivate students to try to use the language correctly as much as they can so they can be well understood. According to Bruner (1999), language learning is effective if students can participate well and do a task well.

Additionally, the study findings are in accordance with the research by Lopez (2004) in Brazil and Tanasarne (2002) in Japan. They found that the group that used task-based language teaching showed higher language abilities compared to the group that only used PPP. Overall, this study shows that taskbased language teaching helps inject the element of linguistic awareness into students and can directly or 
indirectly increase their mastery of effective speaking skills.

In this study, the control group was taught through a conventional approach using the instructional material package designed by Ministry of Education (Singapore). The teaching of speaking skills was more focused on text reading and answering comprehension questions based on video watching or audio listening. After that, they had to recall the scene they had watched or listened to. The students also needed to fill out a graphic arranger as a reference before speaking.

Based on the study findings in Table 5, no significant difference was observed in the vocabulary aspect in the control group before and after treatment (median $=5.00), Z=-.810, p>.05$. Similarly, in Table 6 , the study findings show no significant difference in the language aspect after treatment (median $=6.00$ ) and before treatment (median $=5.00), Z=-1.761, p>$ .05. These findings are in accordance with those of Scrivener (1994), who stated that an approach that follows an organised routine can make students feel in control but can restrict their vocabulary learning and creative usage of the language. Language learning in the context of the conventional approach can provide declarative knowledge but does not guarantee procedural knowledge mastery. These findings are also consistent with the opinions of J. R. Anderson (2000) and DeKeyser (2007), who stated that students who master declarative knowledge fluently and clearly might forget how to use the language because they were not trained or do not have the opportunity to use the language with certain activities and tasks.

\section{Treatment Group and Control Group Pre-test Score Differences}

The Mann-Whitney $U$ test results show higher achievement in the fluency aspect after task-based language teaching for the treatment group (median = 7.00 ) compared to the control group (median $=5.00$ ), $U=190.00, p<.05$. Meanwhile, the same test showed no significant difference between the two groups after treatment in the vocabulary aspect, $U=279.00, p>$ .05 , or in the language aspect, $U=325.50, p>.05$. This is because students from the treatment group underwent tasks without any precision of language use but a primary focus on comprehension. A person who can speak fluently may have imprecise vocabulary and language use but still be understood by the teacher. According to Skehan (1998), this can become a habit of wrong language use. The students in the group might use code-switching while speaking when performing the given task. Additionally, this is a habit of Malay students in Singapore. Therefore, imprecise and wrong use of the language structure can happen with Malay respondents because of codeswitching. Also, this can interrupt their language mastery and vocabulary acquisition, especially if their teachers cannot give any feedback or correct the students' mistakes (Skehan, 1998). This shows that students really need help in vocabulary and language mastery.

In addition, these findings are due to the students' level of mastery and the way the subject is taught. This has been highlighted by task-based language teaching researchers, namely Prabhu (1987), Willis and Willis (2001), Nunan (1989, 2003), and Swan (2005). There is a possibility that the vocabulary used was not precise or suitable, and the students did not get any input or feedback from the teacher.

Insignificant changes may also have occurred because the duration of the study was insufficient. The study was only conducted for only 8 weeks. However, teaching using task-based language teaching approach was only done for 5 weeks. Because of the limited time allocated to the study, some tasks could not be conducted as planned. The 5 weeks of treatment were not sufficient, and the researcher found it difficult to measure the changes and see an immediate improvement in students' oral skills.

In this study, students were exposed to taskbased language teaching approach twice a week for only 5 weeks, consisting of five periods or 2.5 hours only. Students also needed to follow the current learning syllabus for other periods. The study findings supported Krashen's monitor hypothesis (2003), which states that the learning system needs to comply with three main conditions to elicit learning and language mastery. Among them is enough time for the students to focus on the correct structure and form of the language. The same system was also proven by Favreau and Segalowitz (1983) through the information process model, which emphasises the importance of time for students to perform mental activities.

The insignificant change is due to the students' disciplinary and attitude issues in the classroom, their absenteeism, the ability of the teacher to conduct taskbased language teaching, and the emphasis on examination and formative tests in the classroom. This will influence the mastery of vocabulary and language, as the study conducted by Zheng and Borg (2014) in China revealed that task-based language teaching effectiveness was restricted only by the students' discipline in the classroom, the teachers' low capacity for task-based language teaching usage, and the frequent emphasis on examination. Their research is parallel with Li's (1998) study in China, which explained that most teachers were dissatisfied with task-based language teaching because of the limited time and students' negative attitude towards language learning. Although no significant difference was found between the groups in this study, the students in the treatment group had a more positive attitude towards tasks given in task-based language teaching.

\section{CONCLUSION}

Inference statistics analysis showed a significant difference between pre-test and post-test in fluency, vocabulary, and language scores for the treatment 
group, but for the control group, no significant difference was observed between pre-test and posttest scores in fluency, vocabulary, and language. Based on the comparison of achievement scores between both groups, a significant difference was found in the fluency aspect in the post-test, but no significant difference was determined in vocabulary or language. This study adopted a quasi-experimental design and only used pre-test, post-test and questionnaire findings. As such, no classroom observation was conducted by the researcher before or after task-based language teaching approach. For future research, it is strongly recommended that a mixed research design be used.

\section{SUGGESTIONS}

Based on the findings, the researcher would like to suggest the following. First, Malay language teachers must engage students in the classroom by using taskbased language teaching as an alternative method to improve their speaking skills. This would also improve teachers' potential or skills as educators in guiding students to speak Malay.

Second, the task-based language teaching structure needs to be included by Ministry of Education officers when they are developing instructional materials, as these are used widely in all primary schools in Singapore.

Third, the National Institute of Education, an institution that provides pre-service training to teachers, must add task-based language teaching to their training modules. this way, pre-service teachers can teach the Malay language using task-based language teaching once they graduate, consequently enhancing their teaching strategies.

\section{REFERENCES}

Aliakbari, M. \& Jamalvandi, B. (2010). The impact of 'role play' on fostering EFL learners' speaking ability; A task-based approach. Pan-Pacific Association of Applied Linguistics, 14(1), 15-29.

Anderson, J. R. (2000). Learning and memory: An integrated approach ( $2^{\text {nd }}$ ed). Wiley.

Baki, R. (2003). Kaedah pengajaran dan pembelajaran bahasa Melayu. Karisma Publication Sdn. Bhd.

Barnard, R. \& Viet, N. G. (2010). Task-based language teaching (TBLT): A Vietnamese case study using narrative frames to elicit teacher's beliefs. Language Education in Asia, 1(1), 77-86.

Beglar, D., \& Hunt, A. (2002). Implementing taskbased language teaching. In J. C. Richards \& W. A. Renandya (Eds.), Methodology in language teaching: An anthology of current practice (pp. 96-106). Cambridge University Press.

Brown H.D. (2000). Principles in language teaching and learning (4 ${ }^{\text {th }} \quad$ Ed.). A Pearson Education.

Bruner, J. (1999). The culture of education. Harvard University Press.
Buriro, G. A., \& Hayat, T. (2010). Task-based learning: An in-class ELT experiment. Journal of Educational Research, 13, 121-132.

Bygate, M., Norris, J. M., \& Van den Branden, K. (2012). Task-based language teaching. In C. Chapelle (Ed). Blackwell encyclopaedia of applied linguistics. Blackwell.

Chuang, Y. Y. (2010). Implementing task-based language approach to teach and assess oral proficiency in the college EFL classroom. National Science Council.

DeKeyser, R. M. (2007): Introduction: Situating the concept of practice. In R. M. DeKeyser (Ed.): Practice in a Second Language: Perspectives from Applied Linguistics and Cognitive Psychology (pp.1-18). Cambridge University Press.

Ellis, R. (2003). Task-based language learning and teaching. Oxford University Press.

Favreau, M. \& Segalowitz, N.S. (1983). Automatic and controlled processes in the first and secondlanguage reading of fluent bilinguals. Memory \& Cognition, 11(6), 565-574.

Frost, R. (2014). A Task-based approach. British Council Teaching English. http://www.teachingenglish.org.uk/think/methodol ogy/task_based.shtml

Gatbanton, E., \& Gu, G. (1994). Preparing and implementing a task-based ESL curriculum in an EFL setting: Implications for theory and practice. TESL Canada Journal, 11(2), 9-12.

Gopinathan, S. (2010). Globalisation, the Singapore developmental state and education policy: A thesis revisited. Globalisation, Societies and Education, 5(1). 53-70.

Howatt, A. (1984). A History of English Language Teaching. In R. Ellis. (Eds.) Task-based Language Learning and Teaching. Oxford University Press. http://www.moe.gov.sg/media/speeches/1999/20 0199.htm

Krashen, S. (2003). Explorations in language acquisition and use: The Taipei lectures. Heinemann.

Lee, H. L. (1999). Ministerial statement by DPM BG Lee Hsien Loong on Chinese language in schools.

https://www.nas.gov.sg/archivesonline/data/pdfd oc/1999012002.htm

Lee, K. Y. (2012). My lifelong challenge: Singapore's bilingual journey. Straits Times Press.

Li, D. (1998). It's always more difficult than you plan and imagine: Teachers' perceived difficulties in introducing the communicative approach in South Korea. TESOL Quarterly 32, 677-703.

Long, M. H., \& Crookes, G. (1992). Long, M. H., \& Crookes, G. (1992). Three approaches to taskbased syllabus design. TESOL Quarterly, 26(1), 27-56.

Lopez, J. (2004). Introducing TBI for teaching English in Brazil: Learning how to leap the hurdles. In B. 
L. Leaver \& J. R. Willis (Eds.), Task-based instruction in foreign language education (pp. 8395). Georgetown University Press.

Mao, Z. (2012). The application of task-based language teaching to English reading classroom. Theory and Practices in Language Studies, 2(11), 2430-2438

Ministry of Education. (2005). Report of Malay Language Curriculum and Pedagogy Review Committee. Singapore MOE.

Ministry of Education. (2010). Nurturing active learners and proficient users. Report of Malay Language Curriculum and Pedagogy Review Committee. Singapore MOE.

Ministry of Education. (2011). Nurturing active learners and proficient users: 2010 mother tongue languages review committee: Report of Malay language curriculum and pedagogy review committee. Singapore MOE.

Nunan, D. (2010). Task Based Language Teaching. Cambridge: Cambridge University Press.

Plews, J., \& Zhao, K. (2010). Tinkering with tasks knows no bounds: ESL Teachers' Adaptations of Task-Based Language-Teaching. TESL Canada Journal, 28(1), 41.

Prabhu, N. S. (1987). Second language pedagogy. Oxford University Press.

Rohani, S. (2011). Impact of task-based learning on Indonesian tertiary EFL students' employment of oral communication strategies. The International Journal of Interdisciplinary Social Sciences, 5(10), 85-102.

Skehan, P. (1998). A cognitive approach to language learning. Di Dalam Long, M.H. and Doughty, C.J. (Eds.) (2009). The Handbook of Language Teaching. Wiley Blackwell Publication.

Skehan, P. (2001). Tasks and language performance assessment. In M. Bygate, P. Skehan, \& $M$. Swain (Eds.), Researching pedagogic tasks: Second language learning, teaching, and testing (pp.167-185). Harlow, UK: Longman.

Swan M. (2005). Legislation by Hypothesis: The Case of Task-Based Instruction, Applied Linguistics, 26(3), 376-401.
Swain, M. (1985). Communicative competence: Some roles of comprehensible input and comprehensible output in its development. In S. Gass \& C. Madden (Eds.), Input in second language acquisition (pp. 235-256). Newbury House.

Thanh, L., \& Huan, N. (2012). Task-based language learning and student motivation in vocabulary acquisition. Language Education in Asia, 3(1), 106-120.

Torky, S. (2006). The effectiveness of a task-based instruction program in developing the English language speaking skills of secondary stage students. Egypt: Ain Shams University.

Van den Branden, K. (2016). The role of the teacher in task-based language teaching. Annual Review of Applied Linguistics, 36, 164-181.

Van den Branden, K. (Ed.). (2006). Task-based language education: From theory to practice. Cambridge. Cambridge University Press.

Willis, D. (1996). A framework for task-based learning. Longman.

Willis, D., \& Willis, J. (2007). Doing task-based teaching. Oxford University Press.

Zheng, X., \& Borg, S. (2014). Task-based learning and teaching in China: Secondary school teachers' beliefs and practices. Language Teaching Research, 18(2), 205-221. https://doi.org/10.1177/1362168813505941

Zhuo, T. (2019, Nov 9). Keeping the mother tongues alive: Singapore's bilingual challenge. The Straits Times Singapore. https://www.straitstimes.com 


\section{Appendix 1}

(pretest)
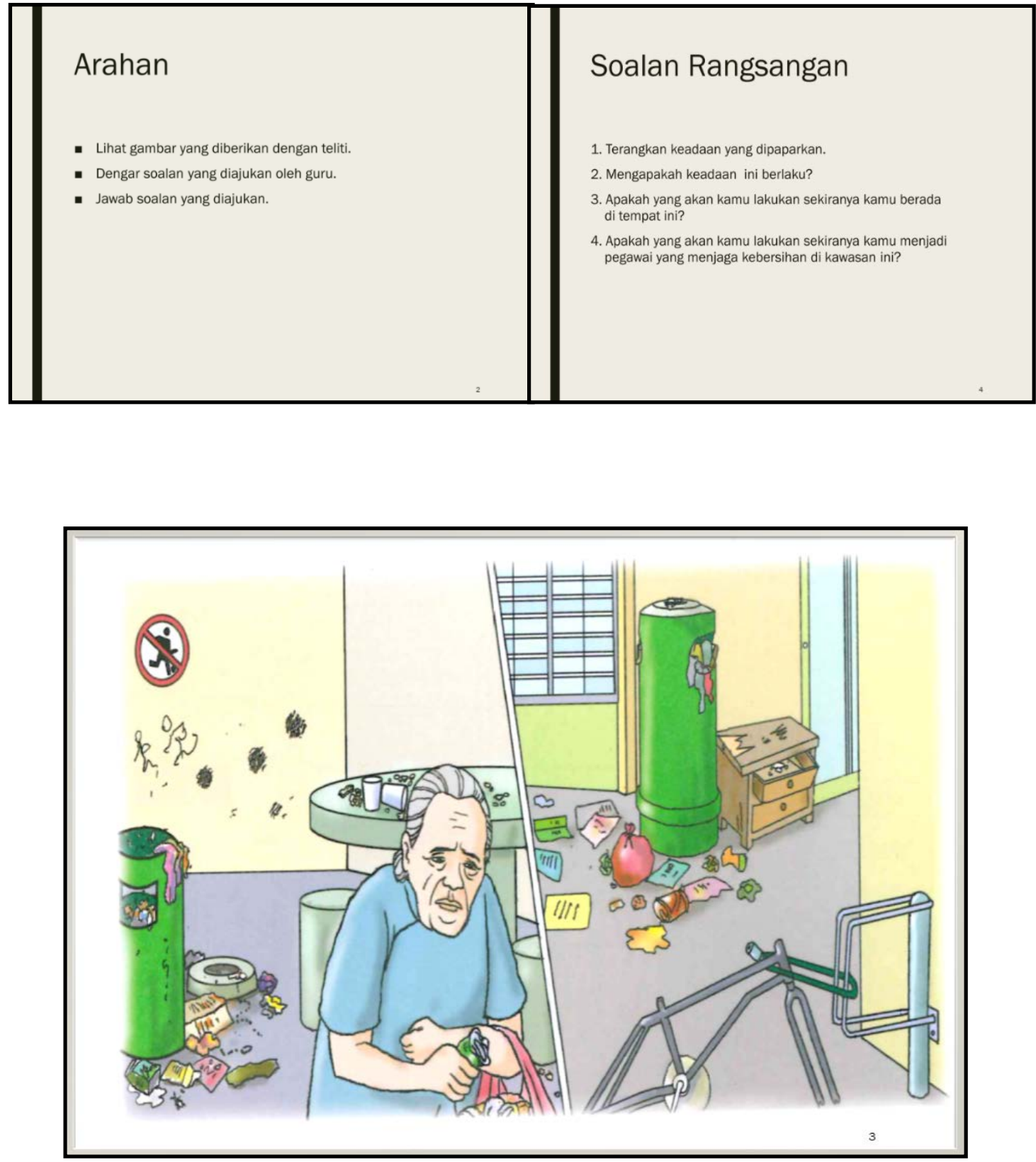

Appendix 2

(Task-Based Language Teaching- sample lesson with materials)

Rancangan Pelajaran (Lesson Plan) 


\begin{tabular}{|c|c|c|}
\hline Masa & : & $\begin{array}{l}60 \text { minit ( } 2 \text { period }) \\
90 \text { minit ( } 3 \text { periods })\end{array}$ \\
\hline Tajuk (Topic) & : & Sihat dan Cergas (Healthy and Active) \\
\hline Objektif & : & $\begin{array}{l}\text { Pada akhir pelajaran murid dapat: } \\
\text { - } \quad \text { bercerita dan melaporkan sesuatu perkara yang didengar, ditonton, di baca atau } \\
\text { dialami } \\
\text { - } \quad \text { menyampaikan maklumat kepada pihak lain dengan pengucapan yang jelas, } \\
\text { betul dan berkesan } \\
\text { menyatakan nama-nama jenis makanan kata adjektif (perasaan dan } \\
\text { pancaindera) }\end{array}$ \\
\hline Tugasan & $:$ & $\begin{array}{l}\text { Makan makanan yang sihat ialah salah satu cara hidup sihat. Pada pendapat kamu } \\
\text { adakah makanan di kantin sekolah kamu menyihatkan? Sekiranya kamu menjadi } \\
\text { pemilik restoran, apakah makanan yang akan kamu sediakan. Sediakan satu menu. }\end{array}$ \\
\hline Bahan & : & - $\quad$ Powerpoint Slides \\
\hline \multirow[t]{2}{*}{ Pratugasan } & : & $\begin{array}{l}\text { Pelajar: } \\
\text { - melihat gambar yang ditayangkan } \\
\text { menjawab soalan yang diajukan oleh guru } \\
\text { a. Adakah kamu akan membeli hidangan lengkap makanan segera? } \\
\text { b. Mengapa? } \\
\text { c. Adakah kamu suka makan di restoran makanan segera? Mengapa? }\end{array}$ \\
\hline & : & $\begin{array}{l}\text { Pelajar: } \\
\text { - } \quad \text { membincangkan soalan 'Pada pendapat kamu adakah makanan di restoran } \\
\text { makanan segera menyihatkan? Mengapa? } \\
\text { - } \quad \text { berbincang secara berpasangan selama } 5 \text { minit } \\
\text { sumbang saran dan menyenaraikan segala jenis makanan yang mereka makan, } \\
\text { tidak makan dan makanan yang diketahui oleh mereka pada kertas sebak secara } \\
\text { berpasangan } \\
\text { - } \quad \text { mendengar penerangan guru tentang objektif pelajaran dan tugasan yang perlu } \\
\text { dilakukan oleh mereka } \\
\text { Guru: } \\
\text { - menerangkan objektif pelajaran } \\
\text { - menunjukkan menu sebagai contoh } \\
\text { memodelkan cara melakukan tugasan yang diberikan }\end{array}$ \\
\hline $\begin{array}{l}\text { Semasa } \\
\text { Tugasan } \\
\text { Persembahan } \\
\text { Tugasan } \\
\text { Tugasan } 1 \\
15 \text { minit }\end{array}$ & : & $\begin{array}{l}\text { Pelajar: } \\
\text { - menyenaraikan semua jenis makanan yang mereka ketahui di kertas sebak } \\
\text { - mengkategorikan makanan mengikut mengikut kumpulan makanan sihat dan } \\
\text { Guru: } \\
\text { - memanan tidak sihat secara individu }\end{array}$ \\
\hline $\begin{array}{l}\text { Tugasan } 2 \\
20 \text { minit }\end{array}$ & : & $\begin{array}{l}\text { Pelajar: } \\
\text { - menyediakan menu secara berpasangan } \\
\text { - } \quad \text { mengiklankan menu mereka kepada kelas } \\
\text { Guru: } \\
\text { - mendengar maklum balas yang diberikan oleh rakan } \\
\quad \text { tentang kesilapan bahasa dan menyatakan cara membetulkan kesilapan } \\
\text { tersebut. }\end{array}$ \\
\hline
\end{tabular}




\begin{tabular}{|c|c|c|}
\hline $\begin{array}{l}\text { Pascatugasan } \\
20 \text { minit }\end{array}$ & : & $\begin{array}{l}\text { Pelajar: } \\
\text { - } \quad \text { mendengar dan memberikan maklum balas kepada menu yang disediakan oleh } \\
\text { - } \quad \text { menyatakan masalah yang dihadapi oleh mereka ketika mempersembahkan } \\
\text { menu mereka } \\
\text { Fokus Bahasa } \\
\text { Guru: } \\
\text { - menulis nama-nama jenis makanan bagi mengenalkan kata nama } \\
\text { - } \quad \text { menyenaraikan perasaan mereka dan perkataan adjektif yang ada kaitan dengan } \\
\text { - } \quad \text { mencaindera seperti sedap, manis dan sebagainya }\end{array}$ \\
\hline Penutup & & $\begin{array}{l}\text { Pelajar: } \\
\text { - } \quad \text { menyatakan cara mereka akan memilih sarapan mereka dan sebab-sebab } \\
\text { makanan itu dipilih. }\end{array}$ \\
\hline
\end{tabular}

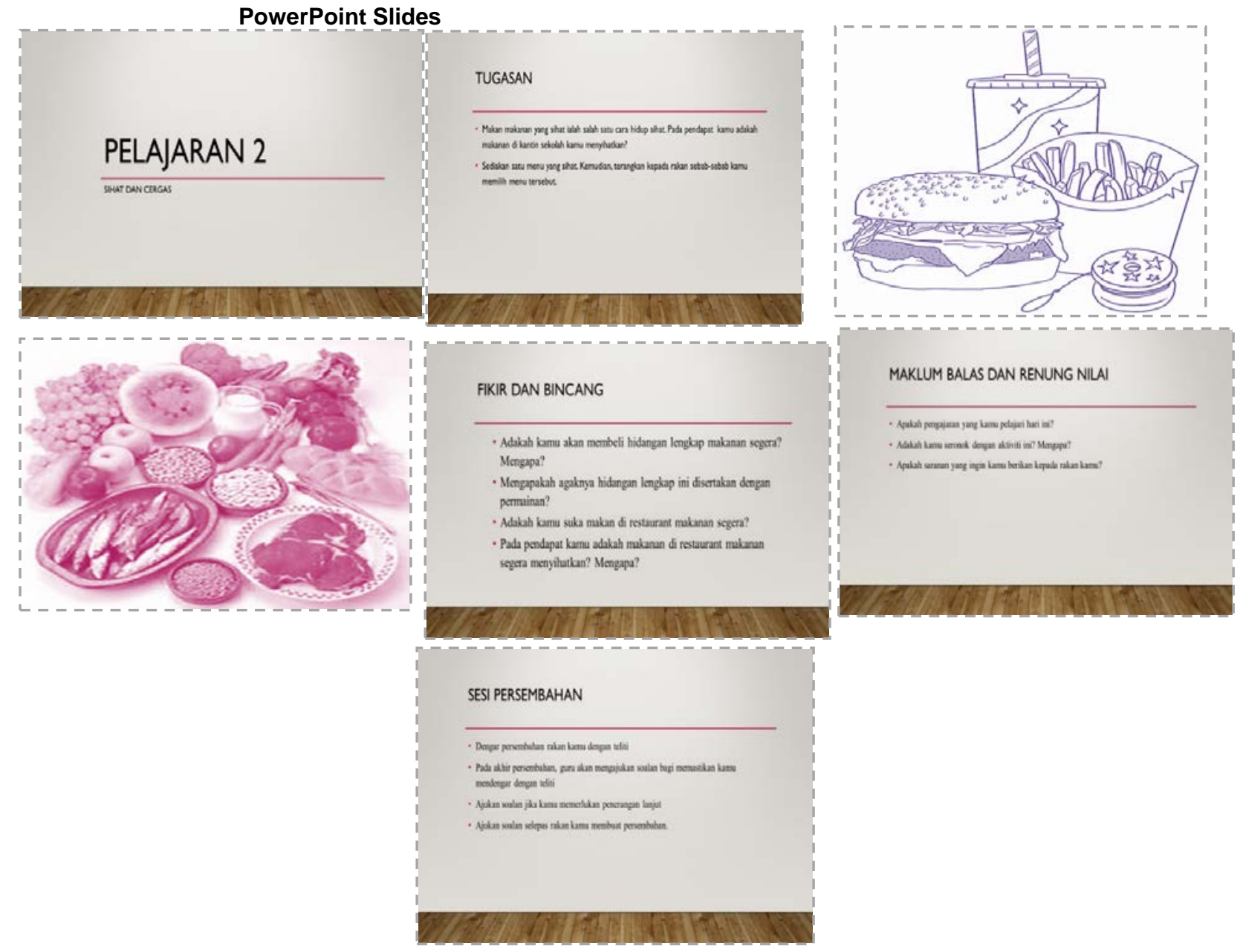

Appendix 3
(Post-test) 
Pasca Ujian Ujian Kemahiran Bertutur

- Lihat gambar yang diberikan dengan teliti.

- Dengar soalan yang diajukan oleh guru.

- Jawab soalan yang diajukan.

\section{Soalan Rangsangan}

1. Lihat gambar ini.

2. Cuba ceritakan apa yang kamu lihat dalam gambar ini.

3. Adakah perbuatan ini betul?

4. Bagaimanakah kita dapat menjaga perhubungan baik dengan jiran.

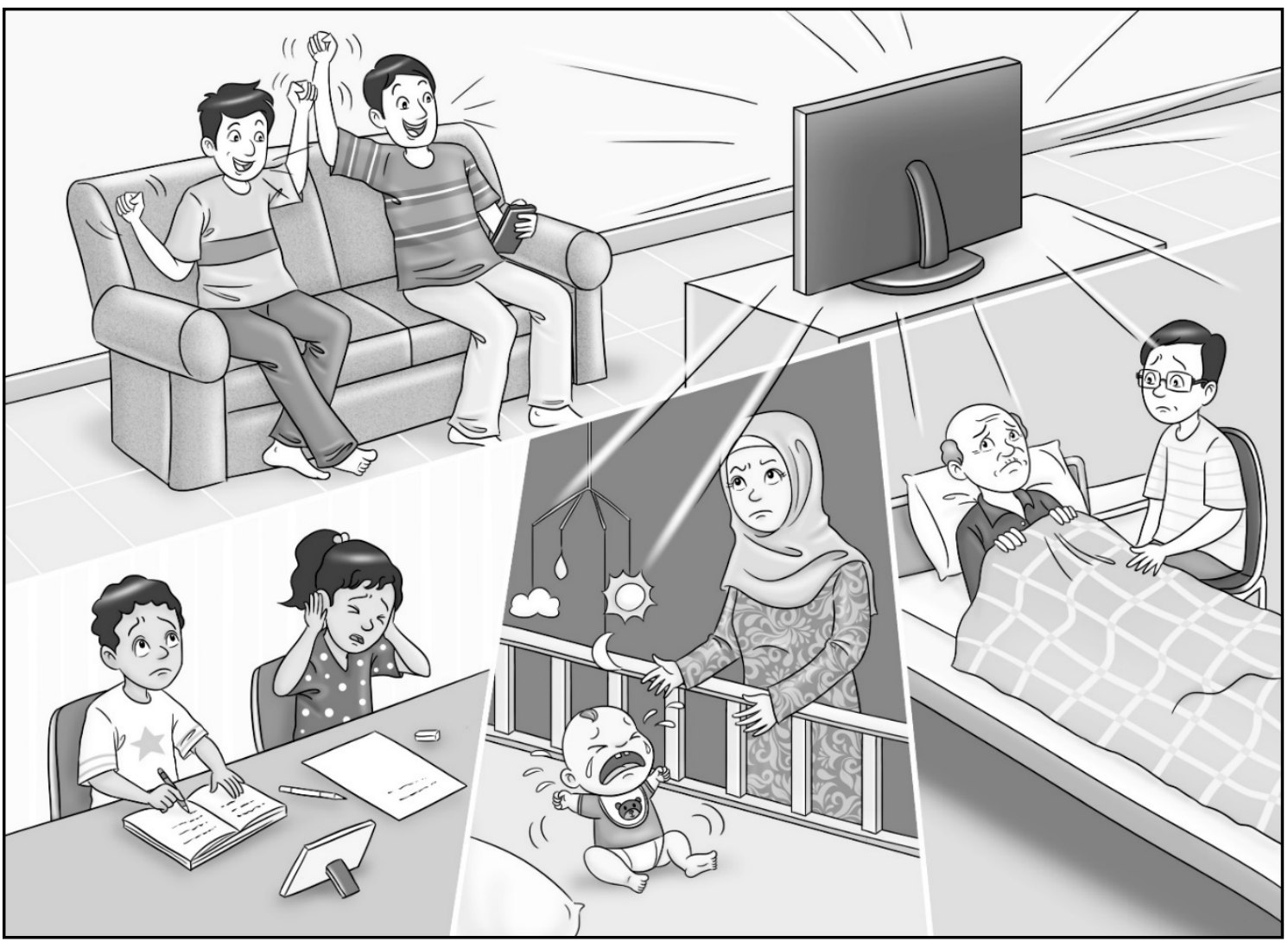

Appendix 4

(Rubric to assess speaking skills) 


\begin{tabular}{|c|c|c|c|c|c|}
\hline Markah & $\begin{array}{c}9-10 \\
\text { CEMERLANG }\end{array}$ & $\begin{array}{c}7-8 \\
\text { SANGAT BAIK }\end{array}$ & $\begin{array}{c}5-6 \\
\text { BAIK }\end{array}$ & $\begin{array}{c}3-4 \\
\text { SEDERHANA }\end{array}$ & $\begin{array}{c}1-2 \\
\text { LEMAH }\end{array}$ \\
\hline KELANCARAN & $\begin{array}{l}\text { - Berupaya } \\
\text { bertutur } \\
\text { dengan } \\
\text { lancar dan } \\
\text { jelas }\end{array}$ & $\begin{array}{l}\text { - Sekali-sekala } \\
\text { tersekat-sekat } \\
\text { tetapi masih } \\
\text { boleh difahami }\end{array}$ & $\begin{array}{l}\text { - Sering } \\
\text { tersekat-sekat } \\
\text { dan } \\
\text { pengulangan } \\
\text { kata tetapi } \\
\text { masih boleh } \\
\text { difahami }\end{array}$ & $\begin{array}{l}\text { - Tidak mampu } \\
\text { bertutur dengan } \\
\text { jelas, kerap kali } \\
\text { terdapat ayat } \\
\text { yang tidak } \\
\text { lengkap }\end{array}$ & $\begin{array}{l}\text { - Tidak mampu } \\
\text { bertutur; } \\
\text { tersekat- } \\
\text { sekat dan } \\
\text { berjeda agak } \\
\text { lama pada } \\
\text { tempat yang } \\
\text { tidak sesuai } \\
\text { hingga } \\
\text { mengganggu } \\
\text { pemahaman }\end{array}$ \\
\hline TATABAHASA & $\begin{array}{l}\text { - Tidak } \\
\text { melakukan } \\
\text { lebih } \\
\text { daripada dua } \\
\text { kesilapan }\end{array}$ & $\begin{array}{l}\text { - Melakukan } \\
\text { sedikit } \\
\text { kesilapan } \\
\text { namun tidak } \\
\text { menjejas } \\
\text { pemahaman }\end{array}$ & $\begin{array}{l}\text { - Sekali-sekala } \\
\text { melakukan } \\
\text { kesilapan } \\
\text { yang } \\
\text { menunjukkan } \\
\text { kurang tepat } \\
\text { penguasaan } \\
\text { pola-pola } \\
\text { tertentu }\end{array}$ & $\begin{array}{l}\text { - Kerap kali } \\
\text { melakukan } \\
\text { kesilapan } \\
\text { kerana belum } \\
\text { menguasai pola- } \\
\text { pola ayat utama } \\
\text { yang } \\
\text { mengganggu } \\
\text { pemahaman }\end{array}$ & $\begin{array}{l}\text { Hampir } \\
\text { keseluruhann } \\
\text { ya tidak betul } \\
\text { dan amat } \\
\text { mengganggu } \\
\text { pemahaman }\end{array}$ \\
\hline KOSA KATA & $\begin{array}{l}\text { Kosa kata } \\
\text { yang tepat } \\
\text { dan sesuai }\end{array}$ & $\begin{array}{l}\text { - Kosa kata } \\
\text { yang } \\
\text { memuaskan } \\
\text { dan masih } \\
\text { boleh } \\
\text { menerangkan } \\
\text { isi }\end{array}$ & $\begin{array}{l}\text { Kosa kata } \\
\text { yang terhad } \\
\text { tetapi masih } \\
\text { berupaya } \\
\text { menerangkan } \\
\text { isi }\end{array}$ & $\begin{array}{l}\text { - Kosa kata yang } \\
\text { terhad hingga } \\
\text { tidak berupaya } \\
\text { meneruskan } \\
\text { pertuturan }\end{array}$ & $\begin{array}{l}\text { - Kosa kata } \\
\text { yang terhad } \\
\text { dan kurang } \\
\text { sesuai hingga } \\
\text { mengganggu } \\
\text { pemahaman } \\
\text { dan tidak } \\
\text { dapat } \\
\text { meneruskan } \\
\text { pertuturan }\end{array}$ \\
\hline
\end{tabular}

